\title{
Unpacking the Syrian Crisis: A Literature Review
}

\author{
Hillary Jephat Musarurwa, Sylvia Blanche Kaye \\ Durban University of Technology, South Africa \\ hmusarurwa2@gmail.com
}

\begin{abstract}
The Syrian war has raged on for more than 4 years now and the global citizenry had decided to keep quiet until recently(Grover, 2015). This paper sets out to explain the Syrian crisis and analyse it in relation to how it affects the global citizenry. It will also lay down the events that have fuelled the crisis, explain some underlying issues and discuss the best possible solutions to address it. When Syrian Arab Spring-type protest erupted experts wrongly predicted that they will frizzle out. What initially started off as protests later became a civil war. The crisis had all the features of a Cold War before the direct involvement of the super powers. The causes of the Syrian crisis are as complex as the different players in it. These key issues go beyond the events of March 2011, which triggered the first shots in Daraa. If this crisis continues uncontrolled it could escalate into World War III. Its end is pinned on the political will and commitment to implement the Vienna Statement of October 30, which incorporates by reference the 2012 Geneva Communique. The lack thereof was witnessed during the short-lived ceasefire of September 2016.
\end{abstract}

Keywords: Syria crisis, humanitarian disaster, migrants, cold war

\section{Introduction}

It is human nature to ignore something that doesnot directly affect as an individual. Several global crises have been met with general akrasia over the past years until after it was too late to save innocent lives. The Syrian war has raged on for more than four years now and the global citizenry had decided to keep silent until recently(Grover, 2015). The pronounce attention to this crisis was triggered by the influx of Syrian refugees onto Europe's doorstep (Heisbourg, 2015). Whilst there was attention before, progress was hampered by the inability for the various players to agree on what to do. The refugee crisis in Europe forced them to see that the inability to solve the Syrian Crisis was now causing more problems. Before that it never bothered or affected state security and the livelihoods of many since it was a drama being acted in the theatre far away in the Middle East. Now the prospects of inviting so called "terrorists" into neighbourhoods has jolted severalcountries and people into action. Whilst countries like Germany and Sweden are making efforts to take in a large portion of the refugees into their borers the rest of the European Union members have not been so enthusiastic. This paper sets out to explain the Syrian crisis and analyse it in relation to how it affects the global citizenry. Because indeed, if conflicts like this one are left uncurtailed can lead to an ever-widening circle of destruction as has been witnessed so far. The article attempts to answer how this global crisis, which has now become a web of foreign players, came about. It will lay down the events that have fuelled it, explain some underlying issues and discuss the best solutions to address the crisis.

\section{Literature Review}

Demographic background: Syria is in the Middle East and is home to about 22 million people. Syria's modern borders were imposed by its former colonisers. This has been a major source of conflict since it forced people from diverse religious and ethnic backgrounds to live within these borders. Due to the fragile composition of its population, Syria has never held a census on religious grounds. It is believed that the Alawites, who rule present-time Syria, are part of the minority. They, together with other non-Sunni Muslim, make a total of about 13\% of the population (Adigbuo, 2014). Sunni Muslims make up 75\% of the population with the remainder being Kurds that inhabit the North-Eastern part of Syria. Syria has been under authoritarian rule by the Baath Party for more than 40 years and the current President Bashar al-Assad took over from his father in 2000.

Chronology of events: News on the Syrian crisis has now dominated international news headlines ever since the heightened push by refugees to reach Europe through legal and illegal entry points. Unworthyservant (2015) illustrates the Syrian conflict as having four opposing sides that at times are not sure whom they are 
really fighting against. However, there is consensus on how events have taken place in Syria since 2011, when the crisis first broke out. Figure 1, below, summarises the timeline of these events.

Figure 1: Syrian crisis timeline

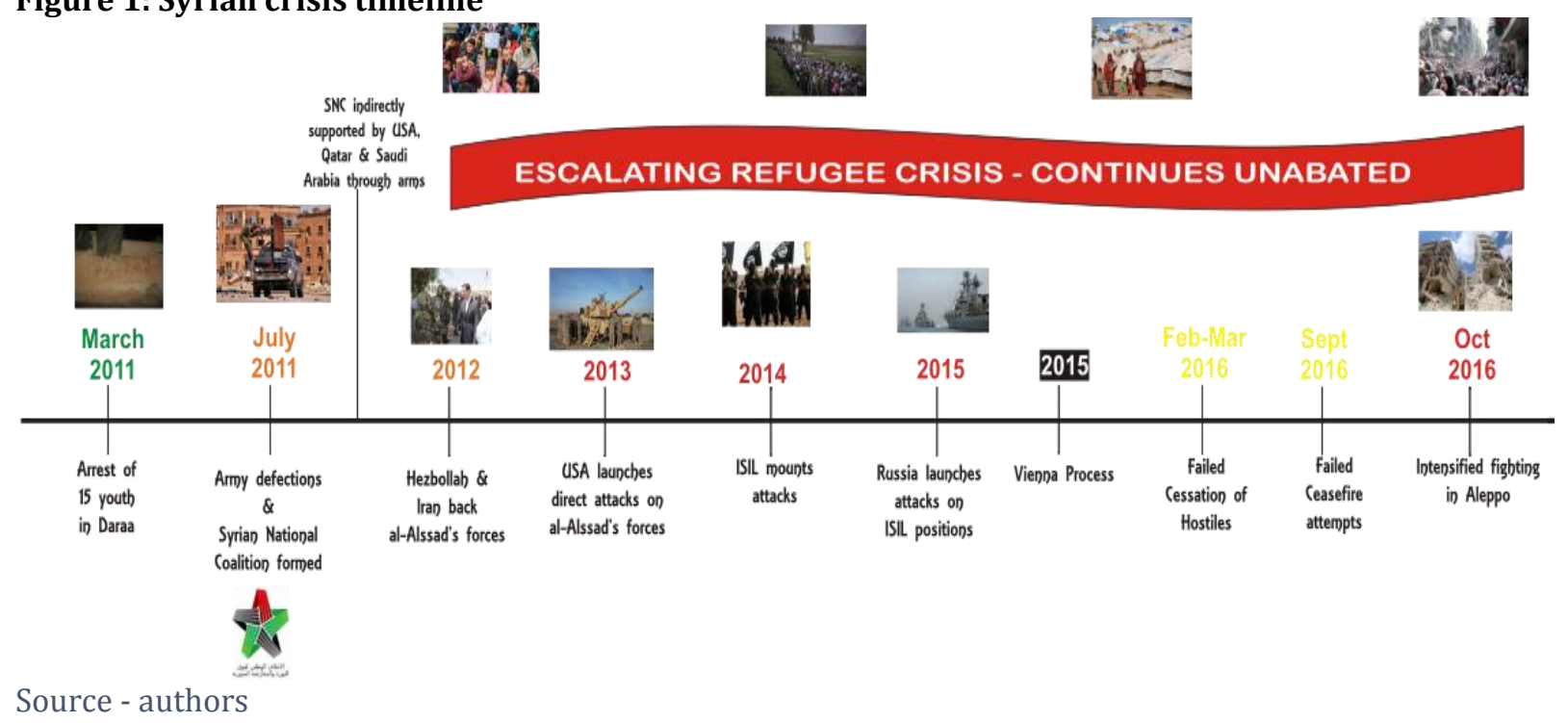

On 6 march of 2011, 15 young people were arrested in the town of Daraa for writing anti-al-Assad graffiti on a wall (Bhalla, 2011). They were tortured during the arrest and this prompted their parents and relatives to take to the streets in protest. The protests were met with a heavy response from the government leading to the deaths of some unarmed civilians. A few days later, a group of those mourning the dead were fired at, leaving one dead. The citizens then armed themselves and returned fire in subsequent protests. When these Arab-Spring-type protests erupted, experts wrongly predicted that they would frizzle our given Syria's stability over the past decades. However, by end of July 2011, some members of the Syrian Army defected, formed the Syrian National Coalition and began fighting against President al-Assad. The Kurds, in the North East, also saw this unfolding civil war as an opportunity to be armed and demand secession from Syria(Gunter, 2015).

Subsequently, the involvement of other countries or foreign groups in the direct confrontation began in 2012 when Hezbollah, with the backing of Iran, fought on al-Assad's side. However, this was probably to counter the indirect participation of other countries like America, Saudi Arabia and Qatar that have been supplyingarms and funding to the Syrian National Coalition, channelling them through Turkey and Jordan (Adigbuo, 2014; Bhalla, 2011; Khashanah, 2014). In 2013, after a protracted delay, the United States of America became involved in direct attacks on those fighting on al-Assad's side (Cozma \& Kozman, 2015). The USA's point of entry was the al-Assad's regime's alleged usage of chemical weapons in the war. 2014 saw the involvement of the Islamic State of Iraq and the Lavent (ISIL) with their quest to set up an Islamic State and Caliphate. The last quarter of 2015 saw Russia'sinvolvement through the direct attacks on ISIL positions. This is reported to be at the invitation of the Syrian government. On 24 November 2015, Turkey gunned down a Russian plane and this event created a diplomatic confrontation between the two countries and NATO. Russia responded by increasing its military posture in the Near East. Whilst China has not been directly involved in the war it has chosen to take a diplomatic rout and use its veto power in the UN's Security Council. This has avoided legitimising international military intervention in Syria despite the itch by so many countries to do so (Swaine, 2012).

No fewer than 17 attempts have been made to try and resolve the conflict(Hartberg, Bowen, \& Gorevan, 2015; Shaw, 2013). These attempts, which started as far back as 2011 and included the involvement of the United Nations, neighbouring states as well as the Arab League, are summarised in the Table 1 below.Despite such concerted efforts the proposed peace plans have failed. The main reason for this failure could be that there have been in some ways too many players and that the disunited agendas of each have continue to plague the 
region and country(Al-Fattal, 2016). There have been reports of mistrust as well as counter-accusations of sides breaching ceasefire agreements and causing more civilian casualties in the process(Crilly, 2016; Issa, 2016).

Table 1: Conflict resolution attempts

\begin{tabular}{|c|c|c|}
\hline Tittle & Date & Lead/Key players \\
\hline Arab League Peace Plans for Syria & $\begin{array}{l}\text { November } 2011 \text { to January } \\
2012\end{array}$ & Arab League \\
\hline Russian Peace Initiatives for Syria & $\begin{array}{l}\text { January } 2012 \text { and November } \\
2013\end{array}$ & Russia \\
\hline Friends of Syria Group & February 2012 & France \\
\hline Kofi Annan Peace Plan & March 2012 & Kofi Annan - UN \\
\hline Geneva I Conference on Syria & June 2012 & United Nations \\
\hline $\begin{array}{l}\text { 16th Summit of The Non-Aligned } \\
\text { Movement }\end{array}$ & August 2012 & Iran \\
\hline Eid Al-Adha Cease Fire Attempt & September 2012 & Lakhdar Brahimi - UN \\
\hline Geneva II Conference on Syria & January 2014 & United Nations \\
\hline Four Committees Initiative & July 2015 & United Nations \\
\hline Zabadani Ceasefire Agreement & September 2015 & Hezbollah \& Iran \\
\hline Vienna Process & October 2015 & $\begin{array}{l}\text { United States, Russia, Saudi } \\
\text { Arabia and Turkey }\end{array}$ \\
\hline Riyadh Conference & December 2015 & Syrian opposition groups \\
\hline Geneva II Conference on Syria & January 2016 & United Nations \\
\hline Syrian Women's Advisory Board & February 2016 & United Nations \\
\hline Cessation of Hostilities & February 2016 & UN, Russia and USA \\
\hline Cease Fire Deal & September 2016 & Russia and USA \\
\hline Lausanne Talks & October 2016 & $\begin{array}{l}\text { U.S., Russia, Saudi Arabia, } \\
\text { Turkey, Qatar and I }\end{array}$ \\
\hline Aleppo Ceasefire & October 2016 & Russia and Syria \\
\hline
\end{tabular}

Source: authors

Two of the latest ceasefire attempts have been short-lived with the first one, of September 2016 lasting seven days. Fighting resumed with Russia and USA accusing each other of initiating the breach to the ceasefire agreement (Dorell \& Hjelmgaard, 2016). The fighting that ensued since 19 September 2016 has led to increased fighting in the Syrian second city of Aleppo. A second cease-fire attempt was made to bring peace in Aleppo but only lasted for 10 hours (Reuters, 2016).

Context: Having narrated the events leading to the Syrian crisis this section reviews the context in which it is unfolding. The crisis is more about a dictatorship, the people's attempt at removing him and his brutal response, also, the effectiveness of their attempts and the role of the international community. This was complicated by interference from external powers who sided with either the dictator or the people. Intervention was seen to be fraught with challenges given that there were so many contributing and conflicting influences. Within countries who considered intervening, there was disagreement of how it could be done, resulting in what is seen to be inaction. This section narrates the key issues and the real reasons when foreign players have become directly involved in the crisis.

\section{Salient causes of the crisis}

The causes of the Syrian crisis are as complex as the players in it. These key issues go beyond the events of March 2011, which triggered the first shots in Daraa. Different positions have been presented to lay out the real issues behind the Syrian crisis and the magnitude of its impact. The much publicised key issue has been a demand for regime change and an end to structural violence and inequality within Syria (Gleick, 2014). This position is supported by Phillips (2015) who pins the crisis on "short-term structural socio-economic, cultural and political factors". Some experts have gone back to the drought that hit Syria between 2006 and 2010 and linked the trigger point to climate change ((Bisaria, 2015; De Châtel, 2014; Verner \& Breisinger, 
2013; Werrell, Femia, \& Sternberg, 2015). It is alleged that during this period al-Assad's government selectively provided wells for farmers and left out a big number of deserving households. As reported by (Gleick, 2014) there had been a long history of conflicts over water in the region. Therefore, climate change can be a plausible trigger point. This view is supported by world leaders like Prince Charles and Secretary John Kerry ((BBC News, 2015; Kasperowicz, 2015; Mills, 2015). The theoretic framework introduced by Khashanah (2014) presents the underlying causes as being sectarianism. Whilst Kfir (2015) relates it to the existence of social group identities that push the deep rooted extremist ideologies of ISIL.

Latent causes for foreign involvement: Understanding the latent causes to the Syrian crisis reveals the Cold War nature of this conflict. They in actual fact may be real reasons why outsiders have dabbled into Syria. Johnson (2015) speaks on these latent causes by questioning the timing of the uprising and signing the Bushehr Memo of 25 June 2011. This agreement created the Iran-Iraq-Syria gas pipeline which will be a major source of gas for Europe and a huge boost to the Syrian government's revenue. The European Union, therefore, might be seen as trying to halt the refugee crisis when in actual fact it wants to ensure that the gas gets into its citizens' homes. The systemic framework introduced by Khashanah (2014) argues that the revolt was used as an entry point to realign Syria ideologically and geopolitically. She introduces a geogram and theory that pits Iran, China and Russia to the "left" and whilst the "right" has USA, Canada, the European Union and Turkey (see Figures 2 and 3 below). Countries such as Qatar and Saudi Arabia that are in the vertical axis of the geogram are part of the right. The aim of the countries involvement is to move Syria to the right. The realignment could be seen as necessary sinceSyria is strategic geopolitically.

\section{Figure 2: Syria's geopolitical and economic footprint} Syria's Pre-Crisis Geogram

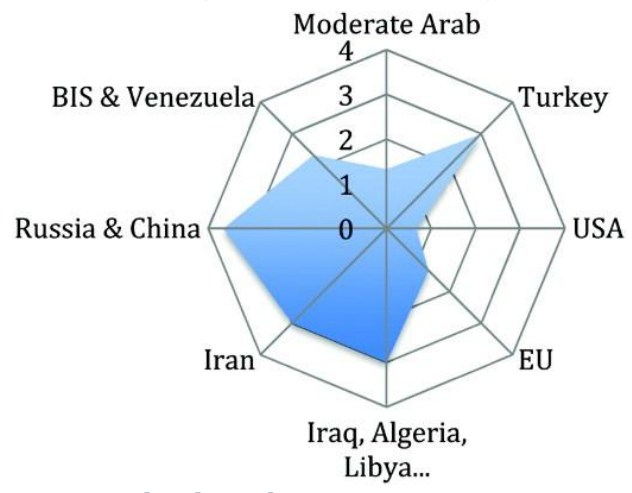

Source Khashanah 2014:13

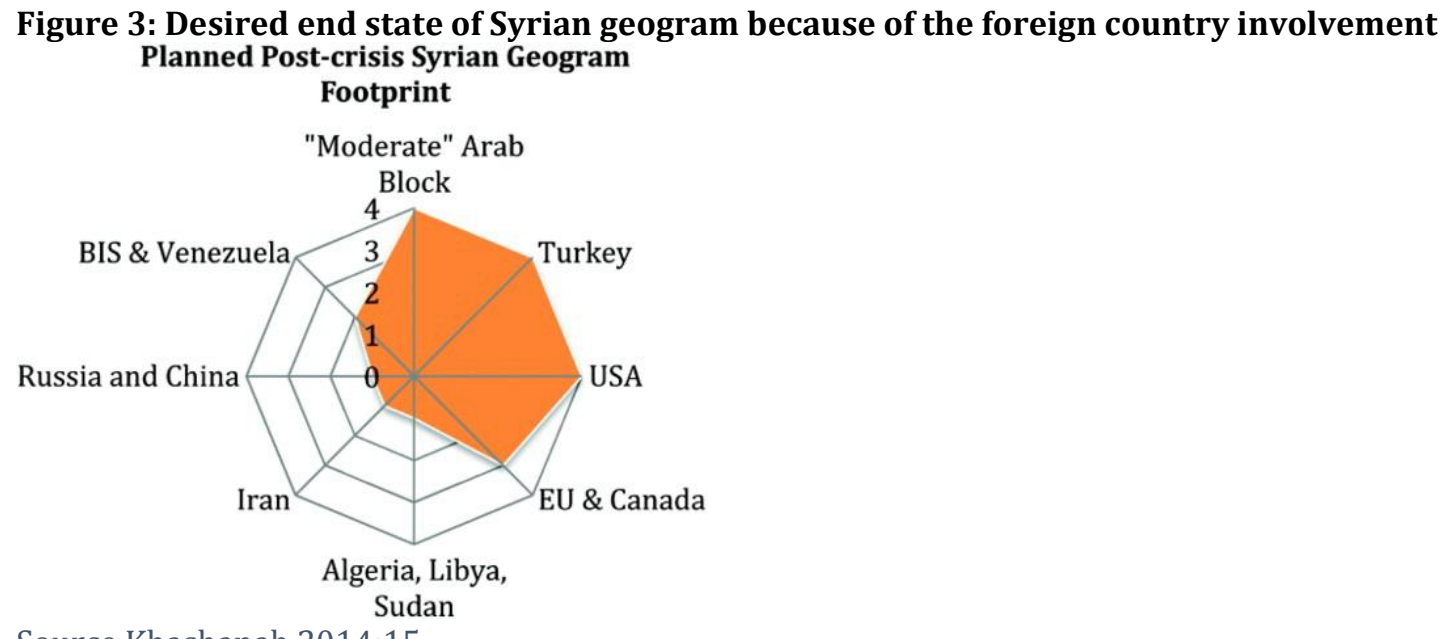

Source Khashanah 2014:15 
Whilst the USA's involvement has been publicised as a reaction to al-Assad's' atrocities and his use of chemical weapons, the latent issue is to push back Iranian influence in the region. On the other hand, Syria is a strategic ally to Russia's sphere of influence in the Middle East and Northern Africa (MENA) region as it hosts Russia's remaining naval base of Tartus(Kreutz, 2010). Russia's involvement is therefore aimed at entrenching its influence in the region as well as a show of military power. This military power has been displayed by Russia's success rate in obliterating ISIL bases and positions regardless of the short-time it has been directly involved in the conflict(Roth, 2016; Stent, 2016). This has prompted the USA to have diplomatic agreements with Russia that they have a common enemy in this war and hence they should increase joint efforts to eliminate ISIL.

War classification: There have been different propositions on the type of war in which the Syrian crisis can be classified. These classifications are linked to the many events that have unfolded over the past four years. Initially, it started off as a civil war, with a citizens' uprising that demanded structural change within Syria (Sterling, 2012). Adigbuo (2014) asserts that this crisis had all the features of a Cold War, pitting the regional and international community, way before the direct involvement of super powers like America and Russia. The main reason for this will be explained in the next section that narrates the underlying issues behind the crisis. Other scholars have classified it as a Holy War pitting Shi'a Muslims against Sunnis ((Bhalla, 2011; Khashanah, 2014). Whilst on the hand scholars reports and conspiracy theorists have hinted that if it goes uncontrolled it could escalate to World War III with the potential usage of nuclear weaponry (Adigbuo, 2014).

Humanitarian impact of the crisis: Whilst the figures of the death toll from Syria vary according to source, it has become the worst crisis in our lifetime, affecting more people that the combined impact of the Haiti Earthquake, the Indian Ocean Tsunami and Hurricane Katrina (World Vision, 2015). Regardless of this fact it has not been met with matching attention and responses. According to United Nations Office for the Coordination of Humanitarian Affairs (2016a) more than 250000 people have been killed in the Syrian crisis. An estimated 4,3 million are now refugees with 6.6 million have been internally displaced. Approximately USD7,7billion is needed to meet the urgent needs in Syria during 2016 with USD5.3billion having been raised by October 2016 (United Nations Office for the Coordination of Humanitarian Affairs, 2016b). The crisis is an evident case of the impact of the international community's failure to fulfil its responsibility to protect global citizens (Solberg-Henriet, 2015).

\section{Solutions to the Syrian conflict}

Concerted efforts have been made to find a lasting solution to this conflict cover the past 2 years. All players have been afforded an opportunity to put their demands on the table and propose their own solutions. Players have different positions dependent on whose side they have been supporting and what their longterm gains will be(Al Jazeera Staff, 2015). For instance, Russia sees a political solution as the only way to being an end to the Syrian crisis(Gardner, 2016). The USA is pushing for a negotiated settlement that might involve not keeping al-Assad in power longer(Shapiro \& Charap, 2014; Tabler, 2013). The Gulf States and Turkey insist on al-Assad's exit and are advocating for setting up a transitional mechanism(Hokayem, 2013). Iran, which has spent billions to prop up al-Assad, proposes a peaceful transition leading to multi-party elections (United States Institute of Peace, 2015). The ongoing negotiations have let to the release of the Vienna Statement of October 30, which incorporates by reference the 2012 Geneva Communiqué(United Nations Department of Political Affairs, 2015). Some of the agreed positions thereof include;

- A ceasefire that establishes a credible, inclusive non-sectarian governance within 6 months

- Drafting of a new constitution

- Holding free and fair elections within 18 months in pursuant of the new constitution

- The elections to be under UN supervision and allowing all Syrians including the Diaspora to participate.

The end of the Syrian crisis is pined on the political will and commitment to implement the above agreed positions to the letter. What is seen is how the parties to this war will act out as the hostilities and engagements continue. 


\section{Conclusion}

From the analysis of available literature, it can be concluded that the causes of the Syrian crisis include the civilian demands for regime change, climate change and inequitable distribution of natural resources, geopolitical positioning of foreign players, religion and sectarianism as well as the scramble for oil and gas by foreign countries. This crisis is a good illustration of how things can go wrong, anywhere in world, if the following can take place:

- Failure to address structural, cultural violence and underlying issues of social exclusion, poverty and inequality

- Applying hard handed responses to protesters demanding structural changes in their states

- Failure to mitigate and address climate change and the scramble for scarce natural resources

- Ignoring the right to protect in favour of the show of political power and prowess

- Putting foreign states interests in a particular country ahead of the interests of that country's citizens

- Failure to eliminate the marketplace of identities and thus promote harmony amongst us.

The fact that billions have been spent in entrenching positions as opposed to addressing the humanitarian crisis is evidence of how greed and power have consumed humanity. Thousands of lives and billions of dollars could have been saved had the world taken appropriate action right from the onset. This is a crisis that could have been avoided and history will judge this generation for not having done enough. It is a good example of why more ethical and collective interventions are the solution to such problems. We will be judged for choosing to ignore a crisis as it morphed up simply because it was not happening within our neighbourhood.

\section{References}

Adigbuo, R. E. (2014). Cold War Resurgence: The Case of Syrian Uprising. Journal Of Humanities And Social Science, 19(8), 39-47.

Al-Fattal, R. (Producer). (2016). Why initiatives to bring peace in Syria have got it wrong. Open Canada. Retrieved from https://www.opencanada.org/features/why-initiatives-bring-peace-syria-have-gotit-wrong/

Al Jazeera Staff. (2015). Analysis: How to solve a problem like Syria? Retrieved from http://www.aljazeera.com/news/2015/09/analysis-plan-save-syria-150930083231637.html

BBC News. (2015). Prince Charles links climate change to Syria conflict. BBC. Retrieved from http://www.bbc.com/news/uk-34897796

Bhalla, R. (2011). Making sense of the Syrian crisis. Retrieved from http://www.stratfor.com/weekly/20110504-making-sense-syrian-crisis

Bisaria, A. (2015). It'll Take All Of 5 Minutes For This Comic To Tell You Why Syrians Are Fleeing Their Motherland. Indian Times, p. Online article. Retrieved from http://www.indiatimes.com/news/world/itll-take-all-of-5-minutes-for-this-comic-to-tell-you-whysyrians-are-fleeing-their-motherland-244888.html

Cozma, R. \& Kozman, C. (2015). The Syrian Crisis in the News: How the United States' elite newspapers framed the international reaction to Syria's use of chemical weapons. Journalism Practice, 9(5), 669686.

Crilly, R. (2016). All sides report Syria ceasefire breaches as UN prepares to deliver aid. The Telegraph. Retrieved from http://www.telegraph.co.uk/news/worldnews/middleeast/syria/12177167/Allsides-report-Syria-ceasefire-breaches-as-UN-prepares-to-deliver-aid.html

De Châtel, F. (2014). The role of drought and climate change in the Syrian uprising: Untangling the triggers of the revolution. Middle Eastern Studies, 50(4), 521-535.

Dorell, O. \& Hjelmgaard, K. (2016). Aid convoy attacked as Syria declares end to week-old cease-fire. USA Today. Retrieved from http://www.usatoday.com/story/news/world/2016/09/19/syria-trucerussia-us-military-cooperation-doubt/90682792/

Gardner, D. (2016). Russia and Iran move towards a political solution for Syria, Online newspaper. Financial Times. Retrieved from https://www.ft.com/content/22fffd48-37c3-11e6-a780-b48ed7b6126f

Gleick, P. H. (2014). Water, drought, climate change, and conflict in Syria. Weather, Climate, and Society, 6(3), 331-340. 
Grover, S. (2015). R2P and the Syrian crisis: when semantics becomes a matter of life or death. The International Journal of Human Rights, 19(8), 1112-1128.

Gunter, M. M. (2015). Iraq, Syria, ISIS and the Kurds: Geostrategic Concerns for the US and Turkey. Middle East Policy, 22(1), 102-111.

Hartberg, M., Bowen, D. \& Gorevan, D. (2015). Failing Syria: Assessing the impact of UN Security Council resolutions in protecting and assisting civilians in Syria.

Heisbourg, F. (2015). The Strategic Implications of the Syrian Refugee Crisis. Survival, 57(6), 7-20.

Hokayem, E. (2013). Syria's uprising and the fracturing of the Levant. In R. Leenders (Ed.). International Affairs, 438, 149-190). (London): Royal Institute of International Affairs.

Issa, A. (2016). Why Syria's Cease-Fires Keep Collapsing. The National Interest.

Johnson, M. R. (2015). Russian forces in Syria: The ISIS fraud and the frantic clamor of a dying empire. Katehon.

Kasperowicz, P. (2015). Kerry: Climate change fueled Syrian refugee crisis. Washington Examiner. Retrieved from http://www.washingtonexaminer.com/kerry-climate-change-fueled-syrian-refugeecrisis/article/2578035

Kfir, I. (2015). Social Identity Group and Human (In) Security: The Case of Islamic State in Iraq and the Levant (ISIL). Studies in Conflict \& Terrorism, 38(4), 233-252.

Khashanah, K. (2014). The Syrian Crisis: a systemic framework. Contemporary Arab Affairs, 7(1), 1-21.

Kreutz, A. (2010). Syria: Russia's Best Asset in the Middle East. Russie. Nei. Visions(55).

Mills, R. (2015). Charles: Syria's War Linked To Climate Change. Retrieved from http://news.sky.com/story/charles-syrias-war-linked-to-climate-change-10338610

Phillips, C. (2015). Sectarianism and conflict in Syria. Third World Quarterly, 36(2), 357-376.

Reuters. (2016). Aleppo: Ceasefire between Russian and Syrian forces ends; civilians, rebels ignore opportunity to leave. ABC Online Services. Retrieved from http://www.abc.net.au/news/2016-1105/rebel-held-zone-of-aleppo-syria-braces-for-renewed-bombing/7997886

Roth, A. (2016). After four months, Russia's campaign in Syria is proving successful for Moscow. The Washington Post.

Shapiro, J. \& Charap, S. (2014). Winning the peace by failing in Geneva. Foreign Affairs, 9.

Shaw, D. (2013, June 2013). Syria - Timeline of Peace Process. Peace and Justice News.

Solberg-Henriet, H. L. (2015). Responsibility to Protect in Application: A Comparative Analysis of Libya and Syria during the Arab spring.

Stent, A. (2016). Putin's Power Play in Syria: How to Respond to Russia's Intervention. Foreign Aff., 95, 106.

Sterling, J. (2012). Daraa: The spark that lit the Syrian flame. CNN. Retrieved December, 15, 2013.

Swaine, M. (2012). Chinese views of the Syrian conflict. China Leadership Monitor, 39(2).

Tabler, A. J. (2013). Syria's Collapse: And How Washington Can Stop It. Foreign Aff., 92, 90.

United Nations Department of Political Affairs. (2015). 14 November 2015, Statement of the International Syria Support Group Vienna. Retrieved from Rome: http://www.un.org/undpa/en/Speechesstatements/14112015/syria

United Nations Office for the Coordination of Humanitarian Affairs. (2016a). Syrian Arab Republic. Retrieved from http://www.unocha.org/syria

United Nations Office for the Coordination of Humanitarian Affairs. (2016b). Total Funding to the Syrian Crisis. Retrieved from https://fts.unocha.org/pageloader.aspx?page=special-syriancrisis

United States Institute of Peace. (2015). Iranian Officials on Syria, Possible Solutions. Retrieved from http://iranprimer.usip.org/blog/2015/oct/01/iranian-officials-syria-possible-solutions

Unworthyservant (Producer). (2015). Syria's war: A 5 minute history. [Video] Retrieved from https://www.youtube.com/watch?v=Cgi9tz3IZWQ

Verner, D. \& Breisinger, C. (2013). Economics of Climate Change in the Arab World: Case Studies from the Syrian Arab Republic, Tunisia and the Republic of Yemen: World Bank Publications.

Werrell, C. E., Femia, F. \& Sternberg, T. (2015). Did we see it coming?: State fragility, climate vulnerability, and the uprisings in Syria and Egypt. SAIS Review of International Affairs, 35(1), 29-46.

World Vision. (2015). Syria war refugee crisis. Retrieved from http://www.worldvision.org/news-storiesvideos/syrian-war-refugee-crisis. 